\title{
O saber médico e o jornalismo especializado em saúde: como uma epidemia se torna notícia
}

\author{
The medical knowledge and the health news: how an epidimic is \\ reported
El conocimiento médico y el periodismo especializado en salud: como una epidemia se convierte en noticia

\author{
Amanda Souza de Miranda | amanda.souzademiranda@gmail.com \\ Universidade Federal de Santa Catarina. Florianópolis, Brasil. \\ Associação Educacional Luterana Bom Jesus (IELUSC). Joinville, Brasil.
}

\section{Resumo}

Neste artigo, analisamos como os casos de microcefalia no Brasil foram noticiados como uma epidemia. As notícias surgiram como alertas e buscaram explicações para o problema, além de discutirem eventuais soluções. A partir do conceito de saber médico e da delimitação de características do jornalismo especializado em saúde, observamos como o conhecimento produzido pelo jornalismo é útil para a disseminação e fortalecimento desse sistema. A cobertura mostrou como os conceitos de biopolítica e governamentalidade ganham dimensões próprias ao enxergarmos o jornalismo especializado em saúde como dispositivo e tecnologia de poder.

Palavras-chave: jornalismo especializado em saúde; saber médico; biopolítica; governamentalidade; narrativa. 


\begin{abstract}
In this article, we analyze how cases of microcephaly in Brazil were reported as an epidemic. The news have came as alerts and sought explanations for the problem, as well as they have discussed possible solutions. From the concept of medical knowledge and from the delimitation of characteristics of health news, we observe how the knowledge produced by journalism is useful for the dissemination and strengthening of this system. The coverage showed how the concepts of biopolitics and governmentality gain their own dimensions when we understand health news as a device and technology of power.
\end{abstract}

Keywords: health news; medical knowledge; biopolitics; governmentality; narrative.

\title{
Resumen
}

En este artículo, se analiza cómo se registraron los casos de microcefalia en Brasil como una epidemia. Las noticias surgieron como alertas y buscaron explicaciones para el problema, y tambien discutieron posibles soluciones. Desde el concepto de conocimiento médico y de la delimitación de las características de periodismo especializado en salud, observamos cómo el conocimiento producido por el periodismo es útil para la difusión y fortalecimiento de este sistema. La cobertura mostró cómo los conceptos de biopolítica y gubernamentalidad ganan dimensiones propias cuando vemos el periodismo especializado en salud como dispositivo y tecnología de poder.

Palabras clave: periodismo especializado en salud; conocimiento médico; biopolítica; gubernamentalidad; narrativa.

Contribuição dos autores: a autora foi responsável por todas as etapas de preparação do artigo.

Declaração de conflito de interesses: não há conflito de interesses.

Fontes de financiamento: não há.

Considerações éticas: não há.

Histórico do artigo: Submetido: 09.abr.2017 | Aceito: 05.maio.2017 | Publicado: 30.jun.2017

Apresentação anterior: não houve.

Licença CC BY-NC atribuição não comercial. Com essa licença é permitido acessar, baixar (download), copiar, imprimir, compartilhar, reutilizar e distribuir os artigos, desde que para uso não comercial e com a citação da fonte, conferindo os devidos créditos de autoria e menção à Reciis. Nesses casos, nenhuma permissão é necessária por parte dos autores ou dos editores. 


\section{Introdução}

O jornalismo e a medicina dividem espaço e ocupam diferentes posições no campo da saúde pública. Se, de um lado, os interesses privados, a ideologia profissional e os modos de produção orientam e moldam o que chamamos de notícia, do outro, o saber médico e a força de um grupo profissional parecem estar acima de qualquer ponto de tensão. Para além deles, a audiência (ou os pacientes) se encontram como pontos finais de processos complexos, orientados por um dispositivo de tecnologia e poder em cuja estrutura básica está a noção de cuidado orientada pelo viés da medicalização.

O ponto de partida deste artigo é de que o jornalismo especializado em saúde se constitui como um dispositivo capaz de direcionar e normatizar hábitos e, ainda, de integrar-se às relações de poder que constituem a biopolítica. Partimos desse pressuposto para refletir acerca de três diferentes momentos da cobertura jornalística sobre os casos de microcefalia no Brasil, no ano de 2016, entendendo os produtos jornalísticos como atores de relevância no que se refere à propagação do saber médico, no sentido foucaultiano.

Agamben $^{1}$ reflete sobre os sentidos do conceito de dispositivo na obra de Michel Foucault lembrando que, entre suas características, está o fato de ter sempre "uma função estratégica concreta" e estar sempre inscrito em uma relação de poder. A partir de declarações dadas pelo próprio Foucault em uma entrevista, ele aponta sua ligação a um conjunto heterogêneo, que pode compreender objetos linguísticos e não linguísticos, discursos, instituições etc.

Compreendemos, portanto, que os produtos jornalísticos - e o jornalismo, em seu conceito mais amplo - constituem-se como dispositivos. Como tais, apresentam uma função estratégica e podem atuar de forma definitiva na normatização e direcionamento de hábitos de higiene, cuidados com o corpo, comportamento etc. É sobre isso que buscamos refletir a partir de um olhar cronológico para a cobertura acerca dos casos de microcefalia, selecionada pela atualidade do assunto e pela sua recorrência na mídia, e compreendendo que, em momentos de tensão social no campo da saúde pública, muitas vezes a mídia assume o protagonismo discursivo.

Para dar conta do nosso objetivo, que é discutir a caracterização do jornalismo especializado como um dispositivo também de normatização, iremos trabalhar com definições de Foucault que consideramos pertinentes à narrativa da cobertura jornalística dos casos de microcefalia no Brasil quando no início da difusão das notícias sobre o assunto. O objeto empírico encontra-se apresentado na última seção, em que analisamos a narrativa de cinco notícias veiculadas em diferentes portais de notícia (os nacionais Folha de São Paulo e G1 e os de origem estrangeira El País e BBC) e selecionadas a partir do critério de relevância do aplicativo Google News. A ideia é compreender a narrativa sugerida pela cobertura desde as suas primeiras publicações até a intensificação dos debates, a partir do que consideramos momentos de virada no enredo.

\section{O jornalismo especializado em saúde: três perspectivas}

Assim como ocorreu com toda a sociedade, a especialização em diferentes áreas também atingiu o jornalismo e lhe conferiu novas características. Conforme Tavares ${ }^{2}$, historicamente esse processo tem relação com a evolução dos meios de comunicação e com a "formação de grupos sociais consumidores de mídia cada vez mais distintos". Tais grupos demandariam produtos jornalísticos segmentados e específicos a determinados interesses da audiência. A saúde corresponde a um desses interesses. Ao fazer uma revisão sobre as características dessa especialização, o autor aponta para um dos papéis que o campo assume: "Atribui-se a esse tipo de jornalismo, portanto, o papel de buscar intermediar saberes especializados na sociedade, construindo um tipo de discurso que, noticioso, ou "apenas informacional, promova um outro tipo de conhecimento que se funde - geralmente - na compreensão conjunta do universo científico e do senso comum." ${ }^{2}$ 
Também no contexto da especialização jornalística está imbuída a compreensão de que existe uma mediação, uma ponte entre o campo de origem da especialização (no caso deste artigo, a saúde), e o conhecimento do leitor. Isso porque a especialização também apresenta a função de "intermediar tematicamente saberes expertos de uma maneira acessível ao público, buscando não apenas transmiti-los, mas também explicá-los. ${ }^{2}$

Para tratar do jornalismo especializado em saúde como esse campo híbrido que problematizamos no presente artigo, partiremos de três reflexões: a primeira é de que ele constitui-se como um campo de produção do conhecimento; a segunda é de que ele opera de modo particular e específico; e a terceira, consequência das duas primeiras, é de que ele não se equipara de modo algum à ciência e à medicina, constituindo-se como um saber de características outras. Essas três definições são basilares para a nossa discussão final, que propõe uma conexão entre noções e conceitos do filósofo Michel Foucault e a cobertura jornalística dos casos de microcefalia registrados no Brasil.

Amparados por teóricos como Parker ${ }^{3}$, Genro Filho ${ }^{4}$ e Meditsch 5 , reconhecemos que a notícia é capaz de levar o leitor a compreender e a conhecer algo, ainda que em diferentes níveis. Em suma, reconhecemos no jornalismo o potencial de produção social do conhecimento. Para Parker ${ }^{3}$, por exemplo, esse conhecimento nada mais é do que um conhecimento "sobre algo" (em contraponto a 'de algo'), quase um meio termo entre um saber vulgar e um saber consolidado. Já para Genro Filho ${ }^{4}$, o jornalismo produz conhecimento cristalizado no singular, ou seja, na factualidade dos objetos ao qual ele direciona sua atenção e nas especificidades que cercam as notícias.

No caso do jornalismo especializado em saúde, autores como Lopes F, Ruão T, Marinho S, Coelho ZP, Fernandes L, Araújo S, e outros colaboradores ${ }^{6}$ destacam que este conhecimento transcenderia ao que desponta de uma relação de comunicação entre médico e paciente. "A comunicação mediática passou a ser entendida como o meio privilegiado para aumentar o conhecimento e a consciência das populações sobre os assuntos de saúde, bem como para influenciar as suas percepções, crenças e atitudes, muito para além do clássico modelo de comunicação médico-paciente. ${ }^{6}$

Nos modelos clássicos, o conhecimento sobre saúde teria espaço nas escolas ou em contato com os médicos. Com a entrada em cena dos produtos midiáticos, a audiência pode compreender o início de uma epidemia, por exemplo, por meio de um trabalho de reportagem, com o aporte de fontes do campo da medicina. Esse conhecimento, é claro, não é o mesmo daquele que chega a um expert, mas pode assumir características que levem à mudança de valores, crenças ou mesmo de adoção de hábitos preventivos. Um caso ilustrativo vem da própria cobertura sobre o 'Zika vírus' - enquanto os cientistas se preocupam em estudar de forma pormenorizada e detalhada cada característica do vírus, os jornais trazem informações topicalizadas e fragmentadas, que podem até ser reconsideradas pela comunidade científica no futuro, com o desenvolvimento de novas pesquisas sobre o tema. Isso significa que os modos de produção se distinguem também por conta da pressão na divulgação de resultados: enquanto o jornalista procura respostas quase que diárias para os problemas, os pesquisadores seguem outro ritmo e outra lógica de produção.

Para Saint Clair7, o poder da mídia faz com que ela assuma um papel de governança sobre a informação em saúde e reivindique o protagonismo na divulgação das informações das instâncias competentes. No bojo dessa relação que estabelece com seus receptores e com os diferentes atores do campo da saúde, despontam a hipótese didática e a hipótese do receptor racional. Na primeira delas, estaria a compreensão de que o jornalismo especializado em saúde serve para a prevenção, com fins pretensamente pedagógicos e com o objetivo de ajudar o receptor a tomar suas decisões. Na segunda, estaria a convicção de que o receptor é racional o suficiente para utilizar essas informações exatamente da forma como elas devem ser utilizadas. Em tese, sugere-se uma relação neutra e igualitária, criticada pelo autor, tal como ocorreria na veiculação governamental de propagandas sedutoras e de "fácil linguagem para a população "menos esclarecida".7 
Como a ciência é produzida processualmente e o jornalismo tem a periodicidade como uma das suas características basilares, este descompasso acaba fazendo com que, muitas vezes, o conhecimento em saúde chegue à população primeiro pelos produtos de largo alcance difundidos pela mídia e, só depois, com mais detalhamento, pelos seus médicos particulares ou pelos cientistas. Isso nos leva à segunda característica que pretendemos debater: o jornalismo especializado em saúde tem modos de produção próprios. Estes dizem respeito às práticas e rotinas dos jornalistas; ao financiamento das empresas jornalísticas e à dependência de fontes técnicas e especializadas (os experts).

No que se refere ao tempo, é importante destacar que o trabalho do jornalista se dá sempre contra o relógio. A ênfase em notícias diárias e a cobertura de epidemias e catástrofes é um bom exemplo disso. Enquanto um cientista pode passar anos buscando a solução para o controle do 'Zika vírus', os jornais trazem a questão ao noticiário, com frequência, muitas vezes com soluções que parecem definitivas. Tal característica promove um conhecimento que deve estar sempre em cheque pela sua falibilidade e pela submissão a um tempo que se preocupa mais com a agilidade do que propriamente com a qualidade.

Além disso, outra característica peculiar do jornalismo diz respeito aos seus financiadores - que podem ser desde instituições do Estado, como o Ministério da Saúde, até laboratórios privados. Os leitores e assinantes também são responsáveis pelo financiamento, o que muitas vezes faz com que assuntos mais vendáveis (ou sensacionalistas, para usar um termo ainda mais contundente) ganhem destaque nos produtos midiáticos. De acordo com Kucinsky ${ }^{8}$, essa temática precisa ser compreendida à luz dos interesses mercadológicos que projeta, pois a saúde se tornou estratégica no campo da comunicação. "Revistas como a Veja produzem capas de saúde regularmente, porque são as capas que vendem, na concepção de mercado que eles têm; mesmo quando está caindo um World Trade Center, eles fazem questão de a cada três ou quatro edições dar uma capa de saúde. [ ] Então nós vemos que há uma espécie dum turbinamento: a saúde é vendida como mercadoria e, portanto, na mídia ela é mais mercadoria ainda, é dupla-mercadoria porque tem que ser muito mercadológica a forma como é apresentada, a forma como é tratada."8

Como outra característica própria de seu modo de produção, o jornalismo especializado em saúde firmase e solidifica-se por amparar-se nas fontes técnicas do campo da saúde. Os entrevistados são profissionais validados por conselhos profissionais, que emprestam seu conhecimento ao jornalista para que este apresente-o ao seu público-alvo. Esse saber é predominantemente traduzido como verdade, justamente por conta da capacidade técnica dos entrevistados. Mais do que isso: a reiteração desse saber confere ainda mais poder às classes profissionais que participam desse processo. Quando essas fontes produzem incerteza, como o que comumente ocorre em caso de epidemias, não raras vezes os produtos midiáticos buscam confrontá-la a fim de que promova certezas - o que popularmente ocorre com o espalhamento de estratégias de prevenção e com a difusão de dicas práticas e utilitárias para o cotidiano.

Mas do mesmo modo que os críticos relativizam a eficácia da sua atuação preventiva, há entusiastas que apontam novas possibilidades oriundas da consolidação do jornalismo em saúde. De acordo com Tabakman ${ }^{9}$, "para cada dólar investido em informação sobre saúde são poupados dois dólares em tratamentos e consultas". Ela evidencia também que conseguir que a mensagem seja bem decodificada pelos receptores é o grande desafio que preocupa (ou deveria preocupar) tanto médicos quanto jornalistas". 9 A autora lembra, ainda, que os assuntos sobre saúde não se restringem aos espaços informativos dos veículos de comunicação: estão também nas séries, reality shows, nas telenovelas e em programas de entretenimento.

Em um outro extremo, reforçando a ideia de que o jornalismo especializado em saúde não pode ser equiparado à ciência (nossa terceira definição), se situa o trabalho de Goldacre ${ }^{10}$, um crítico do tratamento que a mídia dispensa à ciência e, em particular, à saúde. Conhecido por desmentir teses oferecidas pela imprensa, é enfático ao criticar os jornalistas que atuam na área, formados em ciências humanas, não em ciências biomédicas. Segundo ele, os profissionais de comunicação "pouco entendem sobre ciência biomédica, mas usam sua ignorância como se fosse um distintivo de honra". ${ }^{10}$ Para ele, existe um ataque 
implícito em toda a cobertura sobre ciência na mídia e, segundo esse modelo, "a ciência não tem base prática, é incompreensível e formada por figuras de autoridade não eleitas [ ] que fazem afirmações sobre verdades didáticas". ${ }^{10}$

Evidentemente, há que se relativizar tal compreensão, levando em conta que o universo da ciência e do jornalismo são distintos. Enquanto um trabalha com o método e é baseado na validação de suas práticas e processos por parte dos pares, o outro é feito em prazos bastante limitados, com espaço pré-definido e a partir de fontes com disponibilidade para interpretarem e contextualizarem determinados assuntos. Enquanto um é feito tendo diferentes modos de financiamento, muitos deles organismos públicos de fomento, o outro é financiado por grandes empresas e grupos de comunicação. Enquanto um produz conhecimento sistematizado e universal, o outro se concentra na produção de um conhecimento cristalizado no singular.

Mas para além das críticas e perspectivas que assume (aqui apontamos somente três das tantas que podem ser levadas em conta), é importante entender que o jornalismo especializado em saúde tem uma abrangência que não pode ser ignorada e se firma como um campo híbrido capaz de, em algum modo, mediar a voz dos profissionais da saúde e de alavancar suas estratégias de consolidação do saber: um saber compreendido aqui como uma categoria foucaultiana, conforme apresentaremos a seguir.

\section{Do saber médico à biopolítica: contribuições foucautianas ao debate}

Das características do jornalismo especializado em saúde, que elencamos anteriormente, uma em especial é pano de fundo para esta reflexão: a de que o campo apresenta uma real dependência das fontes técnicas especializadas (experts) para se constituir e produzir conhecimento. De forma mais ampla, compreendemos que seus produtos amplificam e reforçam o saber e o poder advindos da medicina.

O saber médico foi amplamente debatido e historiografado por Michel Foucault ${ }^{11,12}$. Em O nascimento da clínica ${ }^{11}$ e Microfísica do poder ${ }^{12}$, ele narra como a medicina pode ser vista como um instrumento de exercício do poder. Para tanto, revisita a Europa dos séculos XVIII e XIX, influenciada pelo pensamento racionalista e pelos ideais positivistas. Na Alemanha, por exemplo, a medicina era tomada como uma força do Estado e havia uma hierarquia entre os médicos. No topo estavam aqueles que administravam a saúde em determinadas regiões. Eram como delegados, com domínio, poder e exercício da autoridade.

A França, já em processo de urbanização, exigia um rígido controle de epidemias e pragas, o que evidentemente também passava pelo controle dos corpos. A vigilância e a inspeção constantes atingiam públicos de todas as classes, mas tinham um objetivo central: os pobres não poderiam contaminar os ricos. Com as vacinas, muito ligadas à ideia de prevenção, conseguiu-se controlar a disseminação de algumas dessas doenças. Apesar disso, na compreensão de Foucault, elas representavam uma forte concepção de controle, o que origina as insurreições na Inglaterra na segunda metade do século XIX. Eram movimentos contra "o controle médico que se abate essencialmente sobre a população pobre". ${ }^{12}$

No século XX, esse movimento ganhou força. Especialmente no pós-guerra, que dizimou milhares de pessoas pelo mundo, a compreensão de corpo, saúde e doença se desloca do indivíduo para o Estado. É, em suma, um momento de "um novo direito, uma nova moral, uma nova economia, uma nova política do corpo.” ${ }^{13}$ No entendimento do autor, aquele contexto ambienta uma somatocracia que desde o seu início já estaria em crise e teria a medicina como uma de suas protagonistas.

Um dos motivos dessa crise seria, segundo ele, o fato de a medicina reassumir a vida e poder "exercer vários efeitos absolutamente fundamentais sobre os seus processos". ${ }^{13}$ Dessa nova característica surgiria aquilo que Foucault denomina de mal-estar, algo que atinge o médico e o paciente, os técnicos e a população. Entendemos que o jornalismo especializado em saúde cumpre o papel de solidificar as representações geradas a partir desse contexto. 
O saber médico surge no mundo do trabalho, da justiça e da segurança - com a emissão de laudos e a realização de perícias, e no cotidiano das nossas relações sociais - como no ato de ser autorizado a se tornar motorista ou frequentar uma academia. Em suma, para quase tudo se recorre a ele, já que a medicina "pode ser perigosa não na medida de sua ignorância e falsidade, mas na de seu saber". ${ }^{13}$ Portanto, ela integra um sistema de poder que se relaciona diretamente com a economia e impacta de forma imediata a sociedade.

No bojo de sua influência e predominância, a figura dos médicos se projeta como a de uma autoridade de poder e relevância, pois é a partir da avaliação técnica dos corpos e das mentes que habitam esses corpos que se passa a regular socialmente os indivíduos, tirando muitas vezes a autonomia do sujeito que é medicalizado. Outrossim, o ato de autoridade não se estende somente aos pacientes, mas sim à sociedade de forma geral. Além disso, estende-se e se dispersa para aquilo que não é patológico, como observa o filósofo com relação à psiquiatria.

Mas, a partir de meados do século XIX, temos uma relação de poder que só se sustenta (e que só se sustenta ainda hoje) na medida em que é um poder medicalmente qualificado que submete a seu controle um domínio de objetos que são definidos como não sendo processos patológicos. Esse mesmo saber tende a analisar processos naturais como se fossem patológicos - como a gravidez, a menopausa ou certas atitudes comportamentais - e a transformar estatísticas em alicerces de seu discurso - como as taxas de natalidade, de morbidade e os números das epidemias. Nos produtos jornalísticos, tais características são bastante visíveis. Questões sociais ou mesmo culturais, muito mais relacionadas à esfera do comportamento humano do que da medicina são sistematicamente exploradas como se demandassem uma explicação médica. Isso ocorre de forma muito recente com as questões da sexualidade, por exemplo. Nas notícias sobre transexualidade, não raras vezes o assunto é abordado do ponto de vista médico e até mesmo psiquiátrico, o que corresponde de forma imediata às reflexões de Foucault: "De modo mais geral, pode-se afirmar que a saúde se converteu em um objeto de intervenção médica. Tudo o que garante a saúde do indivíduo, seja a salubridade da água, as condições da moradia ou o regime urbanístico, é hoje um campo de intervenção médica que, consequentemente, já não está vinculado exclusivamente às doenças. De fato, a medicina de intervenção autoritária em um campo cada vez mais amplo da existência individual ou coletiva é um fato absolutamente característico. Hoje a medicina está dotada de um poder autoritário com funções normalizadoras que vão bem além da existência das doenças e da demanda do doente."13

As estatísticas, por seu turno, seriam uma tecnologia de poder que faz emergir o saber médico em toda a sua especialidade e em seu potencial de pasteurizar e unificar os corpos, com uma função maior da higiene pública ${ }^{14}$. Favoreceria, ainda, a formação e a conformação de um enunciado com efeito de verdade e de poder - expressão que Foucault utiliza para se referir à supralegalidade dos laudos psiquiátricos nos tribunais. No jornalismo, esses números também são comumente utilizados como recurso de objetivação, a fim de conferir credibilidade às notícias. Essa tecnologia emerge para introduzir "mecanismos mais sutis, mais racionais, de seguros, de poupança individual e coletiva, de seguridade, etc."14

Aqui, junto ao surgimento do conceito de biopolítica, o indivíduo moderno aparece problematizado como fruto da fabricação do saber e do poder, como "um novo corpo: corpo múltiplo, corpo com inúmeras cabeças, se não infinito pelo menos necessariamente numerável. É a noção de população". ${ }^{14}$ A partir dessa concepção, o saber médico integra-se como parte da biopolítica, com seu poder exercendo-se no corpo e através do corpo, a fim de garantir mecanismos globais de regulamentação: "[ ] mecanismos, como vocês veem, como os mecanismos disciplinares, destinados em suma a maximizar forças e extraí-las, mas que passam por caminhos inteiramente diferentes. Pois aí não se trata, diferentemente das disciplinas, de um treinamento individual realizado por um trabalho no próprio corpo. Não se trata absolutamente de ficar ligado a um corpo individual, como faz a disciplina. Não se trata, por conseguinte, em absoluto, de considerar o indivíduo no detalhe, mas, pelo contrário, mediante mecanismos globais, de agir de tal maneira que se 
obtenham estados globais de equilíbrio, de regularidade; em resumo, de levar em conta a vida, os processos biológicos do homem-espécie e de assegurar sobre eles não uma disciplina, mas uma regulamentação."14

A medicina pode ser vista, sob esse prisma, como uma atividade social dedicada à regulamentação e normalização da sociedade, em seu entendimento mais homogeneizado e massificado. Como não fala de sujeitos, é imprescindível evidenciar que Foucault não trata os médicos como figuras de dominação, mas vê no seu saber um papel crucial no conjunto das relações de poder de uma época. Essas relações de poder, por seu turno, compõem uma teia ainda mais ampla, nas quais se cruzam questões relacionadas à justiça, à sexualidade etc.

No caso do jornalismo especializado, entendemos que, como produto híbrido, ele é capaz de evidenciar enunciados de verdade, escondendo ou camuflando mecanismos de poder que emanam do saber médico, o que aumenta ainda mais sua eficácia e caráter positivo. Assim, em um caso de epidemia, por exemplo, não raras vezes os produtos jornalísticos participarão dessa teia como dispositivos capazes de assegurar a regulação e o controle. Além disso, acabam alimentando o que Foucault ${ }^{15}$ chama de educação do perigo e cultura do perigo, uma das principais características do liberalismo e força motriz da biopolítica.

É como se o jornalismo, tal como acontece com determinadas áreas do judiciário e sua insistente dependência de laudos, também estivesse vivendo um momento de medicalização, transformando os seus receptores em potenciais "midiapondríacos". Ou, como assegura o próprio Foucault: "Poder-seia dizer, quanto à sociedade moderna, que vivemos em 'Estados médicos abertos', em que a dimensão da medicalização já não tem limite. ${ }^{15}$ Nesses "Estados médicos", a fonte do jornalismo especializado em saúde é duplamente autorizada a dizer o que diz, seja por sua capacidade técnica e seu reconhecimento institucional, seja pelo mito da objetividade construído pelos produtos jornalísticos.

A dependência que o jornalismo especializado em saúde tem dos experts seria, assim, uma dependência do seu saber e do poder que dele deriva. Como potencial produtor de conhecimento, o jornalismo também se alimenta da necessidade de governar corpos e mentes e de normatizar hábitos que culminem em atitudes positivas do ponto de vista biopolítico. No conjunto, esse sistema favoreceria os modos de produção do jornalismo e sua organização interna, além de atrair anunciantes e também a audiência.

\section{A cobertura jornalística dos casos de microcefalia}

Até aqui, debatemos dois conceitos distintos: o jornalismo especializado em saúde e o saber médico e suas relações com a medicalização e a biopolítica. Nossa preocupação, como modo de conclusão deste artigo, é estabelecer uma reflexão conjunta sobre estes conceitos a partir da cobertura sobre os casos de microcefalia no Brasil. Para fazer essa conexão, selecionamos cinco notícias veiculadas em portais de referência entre os meses de novembro de 2015 e janeiro de 2016. Num primeiro rastreamento, chegamos a um total de 30 links e, então, estabelecemos os critérios do recorte: as notícias deveriam ser de portais pertencentes a grupos de comunicação e não poderiam vir de agências - fato recorrente na pré-seleção. Depois, a partir da análise dos títulos e linhas de apoio, escolhemos aquelas que revelavam diferentes momentos da cobertura, que já estava em processo de intensificação.

O principal critério de seleção foi, portanto, a relevância obtida junto ao buscador Google News, que automaticamente elenca os textos de maior e menor relevância de acordo com o termo pesquisado (no caso desse estudo, a ênfase foi nas palavras 'Zika vírus' e 'microcefalia"), seguido de escolhas que possibilitassem uma redução da amostra para uma análise qualitativa mais eficaz. Essas cinco notícias identificam diferentes momentos da cobertura que são pertinentes às conexões teóricas que pretendemos discutir. Esses momentos, que serão debatidos adiante, estão relacionados à ênfase na estatística, à ida aos laboratórios e à busca de soluções para uma ameaça. 
Em fevereiro de 2016, o Google News indicava a ocorrência de mais de 250 mil matérias jornalísticas com as palavras 'Zika vírus' e 'microcefalia. Essas palavras não eram comuns na imprensa até meados do mês de novembro do ano anterior, quando as primeiras notícias de um suposto surto de microcefalia começaram a surgir. A partir daí, seja expondo a incerteza científica ou os riscos da doença, o jornalismo especializado em saúde passou a se portar como um dispositivo de reiteração do saber médico, como um dispositivo da biopolítica.

Nosso olhar para o fenômeno está atento à temporalidade e cronologia da cobertura, e tem como orientação metodológica a análise da narrativa proposta por Motta $^{16}$, que percebe o texto jornalístico como um texto cultural. Com essa metodologia é possível, por exemplo, identificar o fio condutor da estória contada pelas publicações, seus personagens de destaque e seu enredo. Nossas reflexões se concentram particularmente na discussão sobre a linha temporal que une uma notícia à outra e aos seus principais pontos de inflexão e de virada: ou seja, quando uma nova notícia traz outros elementos à cobertura que não eram discutidos até então - quando novos assuntos passam a ser agendados, sedimentando-se no debate público.

Nessa linha do tempo que buscamos traçar de novembro de 2015 até fevereiro de 2016, quando há uma proliferação de notícias sobre o assunto, identificamos três pontos de inflexão distintos, que caracterizam diferentes momentos, os quais pretendemos debater a seguir: o primeiro, de alarme do Estado, que recorre a estatísticas e depoimentos do poder público a fim de anunciar uma espécie de alerta; o segundo, de caracterização da epidemia e de busca de explicações, que recorre ao saber médico para a redução da sensação de risco; e o terceiro, mais ligado à noção de governamentalidade, quando se discute o que se deve fazer diante da ameaça, com foco no debate sobre o aborto das gestantes supostamente infectadas.

Esses pontos de inflexão são considerados, aqui, mudanças de orientação da narrativa hegemônica assumida sobre o assunto. Uma virada na narrativa, no entanto, não representa o fim de uma estória e o início de outra. Como veremos, mesmo enquanto falava sobre o aborto, a imprensa ainda tratava dos números e estatísticas divulgados pelos órgãos públicos. A estória é contada a partir de uma série de elementos, viradas e inflexões, constituindo um enredo que se assenta numa temporalidade, mas que não necessariamente terá um princípio, um meio e um fim organizados.

As primeiras suposições de que o Zika vírus e a microcefalia estariam relacionados surgiram por meio de depoimentos do governo - o que nos vincula a ideia de que o Estado é agente regulador do biopoder. Na notícia "Governo diz que ligação entre Zika e microcefalia é altamente provável"17, publicada pela Folha de São Paulo no dia 17 de novembro, junto ao depoimento de um diretor do Ministério da Saúde, estavam as estatísticas assegurando um crescimento incomum de casos de microcefalia para a época. No mesmo período, o governo lançou mão da "emergência nacional em saúde pública", um recurso de alerta amplamente divulgado pela imprensa.

Conceitualmente é possível ver na divulgação das estatísticas um primeiro deslocamento de uma situação de normalidade para uma situação de risco, um dos grandes motores da lógica de seleção das notícias. Nesse momento, o saber médico precisa operar de forma ainda mais positiva, assim como o corpo - particularmente o da mulher e precisamente o da gestante - passa a ser tomado como alvo do Estado e da biopolítica. "Doenças mais ou menos difíceis de extirpar, e que não são encaradas como as epidemias, a título de causas de morte mais frequente, mas como fatores permanentes - é assim que as tratam - de subtração das forças, diminuição do tempo de trabalho, baixa de energias, custos econômicos, tanto por causa da produção não realizada quanto dos tratamentos que podem custar. Em suma, a doença como fenômeno de população: não mais como a morte que se abate brutalmente sobre a vida - e a epidemia - mas como a morte permanente, que se introduz sorrateiramente na vida, a corrói perpetuamente, a diminui e a enfraquece."14

Assim, nossa primeira conexão entre os conceitos apresentados e a cobertura dos casos de microcefalia parte da constatação de que o jornalismo se apresenta como dispositivo da biopolítica na medida em que 
reproduz estatísticas e reitera o saber médico ao apresentá-lo como única forma de compreensão de uma epidemia geradora de incertezas.

Em um segundo momento, como primeiro ponto de inflexão ou de virada narrativa, o jornalismo especializado em saúde partiu para os laboratórios para sinalizar o que os cientistas estavam estudando e poderiam explicar sobre o Zika vírus e sobre a microcefalia. Por seus modos de produção específicos e por sua distinção radical da ciência enquanto campo de produção do conhecimento, é pouco usual que as notícias tratem de processos - no geral, elas se concentram em resultados mais ou menos sólidos e validados pela comunidade científica. Nesse momento, no entanto, um novo deslocamento leva os produtos jornalísticos a canalizarem no saber médico uma esperança de tratamento e de cura.

Em 8 de janeiro, por exemplo, a Folha de São Paulo assegurou que "Para cientistas, surto de microcefalia pode ter fatores adicionais ao Zika"18, enquanto em 27 de janeiro ${ }^{19}$ o portal G1 Rio de Janeiro, que pertence à Rede Globo, noticia que um laboratório do Rio de Janeiro tenta replicar a microcefalia. Embora não seja interesse deste artigo fazer uma análise detalhada das notícias, podemos afirmar que esse segundo momento da cobertura pretende se fiar no saber médico a fim de garantir algum nível de certeza à cobertura. Esse movimento pode ser entendido como positivo para os veículos de comunicação e também para a medicina, que se institucionaliza enquanto campo vital para um momento de risco.

Uma das informações do texto da Folha de São Paulo, por exemplo, assegura que grandes hospitais [ ] e laboratórios de referência já estão com acesso à tecnologia que deve avançar mais para ser mais rápida, prática e eficiente nos 'próximos meses. ${ }^{18}$ No texto do G1 Rio de Janeiro, por outro lado, há mais espaço para as incertezas, construídas na própria fala dos entrevistados. Ainda assim, há um misto de otimismo e convicção no saber médico, como no trecho que informa que as primeiras infecções em laboratório deverão ser realizadas dentro de um mês, tempo necessário para que as equipes obtenham uma carga de vírus suficiente para o experimento. ${ }^{19} \mathrm{O}$ texto sinaliza que o sucesso do experimento só depende da existência de uma carga de vírus suficiente, ou seja: há confiança, ainda que exista incerteza.

Além disso, também nesse momento da cobertura conseguimos identificar os primeiros sinais de disseminação da economia política da medicina, conceito do qual Foucault também trata. É como se, a partir do saber médico, se pudesse gerir uma força econômica que interessa à humanidade. "Não simplesmente porque é capaz de reproduzir a força de trabalho, mas porque pode produzir diretamente riqueza, na medida em que a saúde constitui objeto de desejo para uns e de lucro para outros. Tendo-se convertido em objeto de consumo que pode ser produzido por uns - laboratórios farmacêuticos, médicos etc. - e consumido por outros - os doentes potenciais e atuais -, a saúde adquiriu importância econômica e se introduziu no mercado". ${ }^{13}$

Esse interesse econômico também é benéfico ao jornalismo, que encontra tais laboratórios, farmacêuticos e médicos como seus potenciais anunciantes e financiadores, o que confere uma espécie de retroalimentação ao sistema: o anunciante precisa dos produtos jornalísticos para ter visibilidade e a visibilidade lhe provém os recursos para anunciar. É como se um círculo se fechasse.

Por último, entendemos que a cobertura dos casos de microcefalia chegou a um terceiro momento, no qual as notícias sugerem uma ideia de controle e governo dos corpos, o que nos aproxima do conceito de governamentalidade. Para Foucault, a governamentalidade seria um conjunto de técnicas (ou de dispositivos) para dirigir o comportamento de uma população que foi criada pelo binômio poder/saber. Em uma das tantas conceituações, ele diz que a governamentalidade é "a maneira como se conduz a conduta dos homens"12 - um tipo de racionalidade que rege diferentes estratégias de poder.

No dia 31 de janeiro, o site El País, do grupo espanhol Prisa, publicou uma notícia com o título "Casos de microcefalia voltam a colocar o aborto em pauta no Brasil” ${ }^{20}$. A dimensão do conteúdo transcende o que seria comum vermos numa editoria de saúde e ocupa o espaço de política - uma espécie de indicador de que os próprios jornalistas entendem que não estão mais a tratar somente de saúde ou doença. 
O destaque da reportagem é uma proposta sugerida ao Supremo Tribunal Federal (STF) para que gestantes com fetos identificados com microcefalia possam fazer aborto. Uma das entrevistadas, a antropóloga Débora Diniz, destaca que se trata de uma medida de proteção aos direitos da mulher. O texto segue com debate sobre o aborto na legislação brasileira e sobre as condições básicas - essas, sim, direcionadas pelo saber médico - para que o procedimento possa ser feito. O mesmo assunto também foi pautado pela Folha de São Paulo, em 31 de janeiro, ao identificar que Grávidas com zika fazem aborto sem confirmação da microcefalia. ${ }^{21}$

Em outra direção, o portal da BBC, grupo público da Inglaterra com recente instalação no Brasil, traz, no dia $1^{0}$ de fevereiro, o depoimento de uma jovem sob o título Sou plena, feliz e existo porque minha mãe não optou pelo aborto, diz jornalista com microcefalia. ${ }^{22}$ Pouco comum no jornalismo, o texto é o depoimento em primeira pessoa de uma jornalista que leva uma vida normal mesmo com a síndrome: "Porque a microcefalia é uma caixinha de surpresas. Pode haver problemas mais sérios, ou não. Acho que quem opta pelo aborto não dá nem chance de a criança vingar e sobreviver, como aconteceu comigo e com tanta gente que trabalha, estuda, faz coisas normais e tem microcefalia" ${ }^{22}$, diz ela, defendendo que haja mais informação e discordando da proposta levada pela antrópologa Débora Diniz ao Supremo. O texto foi replicado também pelo Portal G1 Rio de Janeiro, que adquire conteúdo do grupo britânico.

Nesse terceiro momento de uma cobertura ainda recente, percebe-se que o jornalismo parte para um debate de dimensões que extrapolam o saber médico, ainda que de certa forma recorram a ele para entender em quais situações o aborto é possível. Nesse debate, poder e saber formam um binômio forte e sólido no fortalecimento da biopolítica e da governamentalidade.

Na direção da biopolítica, podemos refletir sobre o aspecto de higienização em direção a um corpo mais saudável e mais produtivo. As vacinas em fase de estudo também seriam uma estratégia neste sentido, assim como as constantes manifestações dos agentes públicos e organismos de saúde, que tratam a população como uma massa a ser governada - tal como Foucault ao pensar o conceito: "[...] para administrar essa população, é necessária, entre outras coisas, uma política de saúde capaz de diminuir a mortalidade infantil, de prevenir as epidemias e de fazer baixar a taxa de endemia, de intervir nas condições de vida, para modificá-las e impor-lhes normas (quer se trate de alimentação, de hábitat ou de urbanização das cidades) e proporcionar equipamentos médicos suficientes. O desenvolvimento a partir da segunda metade do século XVIll do que foi chamado Medezinische Polizei, hygiene publique, social medicine, deve ser inscrito no marco geral de urna "biopolítica": esta tende a tratar a "população" como um conjunto de seres vivos e coexistentes, que apresentam características biológicas e patológicas específicas."22

A discussão sobre o aborto em caso de confirmação de microcefalia está longe de acabar, pois o debate continua se acirrando. O conceito de governamentalidade também é essencial aqui para nos provocar a refletir sobre como o jornalismo se constitui como dispositivo para assegurar a "condução de uma conduta"22, precisamente a de mulheres grávidas. Essas discussões dificilmente chegariam ao público mais amplo não fossem os produtos jornalísticos - que ora dimensionam o aborto como uma questão política e social, ora reduzem o debate às questões relacionadas ao saber médico.

O depoimento da jornalista com microcefalia é emblemático nesse sentido, pois ao mesmo tempo que ela surge como uma resistência ao poder, ela alimenta essa mesma teia e dispersa seus significados. Ao discordar das mulheres que optam pelo aborto, ela também produz um discurso normativo e orientativo, ainda que, em outros momentos do texto, sugira que a escolha deva ser da mãe. O que se vê neste terceiro momento, portanto, é uma vigilância da saúde populacional, com sucessivos disparos de discursos de alarme e de risco e recorrendo-se ao saber médico como uma das formas para minimizar os riscos.

Se a cobertura jornalística sobre os casos de microcefalia começou em tom de dúvida, muito mais como uma forma de anunciar uma anormalidade nas estatísticas, na sequência ela ganhou contornos que conferem ao dispositivo jornalismo especializado em saúde uma função chave nessa engrenagem: ele se 
comporta como canal de amplificação e propagação do saber médico e de orientação e normatização para se conduzir a conduta dos homens. Em suma, é um dispositivo biopolítico que produz tensionamentos na relação entre indivíduo e sociedade. Como tal, precisa ser estudado e compreendido em todas as suas complexidades narrativas, como um dos elementos que fazem parte do nosso cotidiano, possibilitando um exercício de entendimento de mundo. ${ }^{23}$

\section{Referências}

1. Agamben G. O que é o contemporâneo e outros ensaios. Honesko VN, tradutor. Chapecó: Argos; 2009. O que é um dispositivo? p. 25-51.

2. Tavares FMB. O jornalismo especializado e a especialização periodística. Est Comun [Internet]. 2009 maio [citado em 8 jan. 2016];5(1):115-33. Disponível em: http://www.ec.ubi.pt/ec/05/pdf/06-tavaresacontecimento.pdf.

3. Park RE. A notícia como forma de conhecimento: um capítulo dentro da sociologia do conhecimento. In: Marocco B, Berger C, organizadores. A era glacial do jornalismo: teorias sociais da imprensa. Vol. 2. Porto Alegre: Sulina; 2008. p. 51-70.

4. Genro Filho A. O segredo da pirâmide: para uma teoria marxista do jornalismo. Florianópolis: Insular; 2014.

5. Meditsch E. O jornalismo é uma forma de conhecimento? Bib on line Ci Com 1997 [citado em 12 dez. 2013]:[cerca de 13 p.]. Disponível em: http://www.bocc.ubi.pt/pag/meditsch-eduardo-jornalismoconhecimento.pdf.

6. Lopes F, Ruão T, Marinho S, Coelho ZP, Fernandes L, Araújo $S$, et al, organizadores. A saúde em notícia: repensando práticas de comunicação [Internet]. Braga: Universidade do Minho, Centro de Estudos de Comunicação e Sociedade; 2013 [citado em 12 dez. 2013]. Disponível em: http://www.ics.uminho.pt/ uploads/eventos/EV 8167/20131217286093508750.pdf.

7. Saint Clair ET. A depressão como atualidade midiática no Brasil contemporâneo: fazendo o arquivo falar (1970-2010) [tese on line]. Rio de Janeiro: Universidade Federal do Rio de Janeiro; 2012. 253 p. Disponível em: http://www.pos.eco.ufrj.br/site/teses dissertacoes interna.php?tease=2.

8. Kuscinsky B. Jornalismo e saúde na era neoliberal. Saúde Soc. 2002 [citado em 10 out. 2013];11(1):95103. Disponível em: http://www.scielo.br/pdf/sausoc/v11n1/10.pdf.

9. Tabakman R. A saúde na mídia. São Paulo: Summus Editorial; 2013.

10. Goldacre B. Ciência picareta. São Paulo: Civilização Brasileira; 2013.

11. Foucault M. O nascimento da clínica. Rio de Janeiro: Forense Universitária; 2006.

12. Foucault M. Microfísica do poder. Rio de Janeiro: Graal; 1998.

13. Foucault M. Crise da medicina ou crise da antimedicina. Verve [Internet] 2010 out. [citado em 8 jan. 2016];18(1):167-94. Disponível em: https://revistas.pucsp.br/index.php/verve/article/view/8646/6432.

14. Foucault M. Em defesa da sociedade: curso no Collège de France (1975-1976). São Paulo: Martins Fontes; 2002.

15. Foucault M. Nascimento da biopolítica: curso no Collège de France (1978-1979). São Paulo: Martins Fontes; 2008.

16. Motta LG. Análise crítica da narrativa. Brasília: Editora UnB; 2013.

17. Cancian N. Governo diz que ligação entre zika e microcefalia é altamente provável. Folha de São Paulo [Internet] (Grupo Folha). 2015 nov. 17. [citado 01 fev. 2016]. Cotidiano. Disponível em: http://www1. folha.uol.com.br/cotidiano/2015/11/1707673-governo-diz-que-ligacao-entre-zika-e-microcefalia-ealtamente-provavel.shtml.

18. Marques J. Para cientistas, surto de microcefalia pode ter fatores adicionais ao zika. Folha de São Paulo [Internet] (Grupo Folha). 2016 jan. 8. [citado 01 fev. 2016]. Cotidiano. Disponível em: http://www1. folha.uol.com.br/cotidiano/2016/01/1727477-para-cientistas-surto-de-microcefalia-pode-ter-fatoresadicionais-ao-zika.shtml. 
19. Ferreira A. Estudo tenta replicar microcefalia no Rio. Portal G1 Rio de Janeiro [Internet] (Grupo Globo). 2016 jan. 27. [citado 01 fev. 2016]. Disponível em: http://g1.globo.com/rio-de-janeiro/noticia/2016/01/ zika-virus-estudo-tenta-replicar-microcefalia-em-laboratorio-no-rio.html.

20. Oliveira AA. Casos de microcefalia voltam a colocar o aborto em pauta no Brasil. El País: o jornal global [Internet] (Prisa). 2016 jan. 31. [citado 01 fev. 2016]; Brasil. Disponível em: http://brasil.elpais.com/ brasil/2016/01/29/politica/1454103307 984282.html.

21. Senra R. Sou plena, feliz e existo porque minha mãe não optou pelo aborto. BBC Brasil [Internet] (BBC New Broadcasting House). 2016 fev. 01. [citado 04 fev. 2016]; BBC São Paulo. Disponível em: http:// www.bbc.com/portuguese/noticias/2016/02/160201 microcefalia aborto pontodevista ss

22. Foucault M. Segurança, território e população. São Paulo: Martin Fontes; 2008.

23. Silva G. Jornalismo e construção de sentido: pequeno inventário. EJM [Internet]. 2005 jul. [citado 4 maio 2017];2(2):95-107. Disponível em: https://periodicos.ufsc.br/index.php/jornalismo/article/ view/2145/1855. 